\title{
Assessing the Spatial Distribution of Biodiversity in a Changing Temperature Pattern: The Case of Catalonia, Spain
}

\author{
Diego Varga ${ }^{1,2,3}$, Mariona Roigé ${ }^{4}$, Josep Pintó ${ }^{2}$ and Marc Saez ${ }^{1,3, *(D)}$ \\ 1 Research Group on Statistics, Econometrics and Health (GRECS), University of Girona, 17003 Girona, Spain; \\ dievarga@gmail.com \\ 2 Landscape Analysis and Management Laboratory, University of Girona, 17004 Girona, Spain; \\ josep.pinto@udg.edu \\ 3 CIBER of Epidemiology and Public Health (CIBERESP), 28029 Madrid, Spain \\ 4 Bio-protection Research Centre, Lincoln University, Lincoln P.O. Box 85084, New Zealand; \\ mariona.roige.valiente@gmail.com \\ * Correspondence: marc.saez@udg.edu; Tel.: +34-972-418-338
}

Received: 3 August 2019; Accepted: 18 October 2019; Published: 21 October 2019

\begin{abstract}
The impacts that climate change and land-use dynamics have on biodiversity are already visible in the distribution and behaviour of a large number of species. By using a Bayesian framework, including land-use, meteorological, topography and other variables as explanatory variables, such as distance to roads and urban centres, we modeled a number of species within each cell of a regular lattice for Catalonia, Spain, in the period of 2004 to 2010. We estimated a slight increase in daily maximum temperature and a more significant increase in minimum temperature (a 5-year increase of $0.159^{\circ} \mathrm{C}$ in maximum temperature, and an increase of $0.332{ }^{\circ} \mathrm{C}$ in minimum temperature). The estimation shows that the total number of species was greater than expected in the cells where land use was not urban-38.4\%, in forests and $55.2 \%$ in mixed forests. Finally, we observed that most invasive species are found in areas where the minimum temperature is expected to increase. Our study can help with making important recommendations as to where, when and how future threats could affect specie distribution and the kind of planning processes needed for when protected natural areas will be unable to continue to support all the species they were designed to protect.
\end{abstract}

Keywords: biodiversity; catalonia; climate change; geographic range; land use; temperature

\section{Introduction}

Climate change represents a significant threat to global biodiversity and natural ecosystem integrity. In the last century, the global average temperatures have risen by $0.7^{\circ} \mathrm{C}$ and are predicted to continue rising (IPCC 2013). Future warming in the Mediterranean basin is expected to exceed global rates by $25 \%$, notably with summer warming at a pace $40 \%$ higher than the global mean. A global atmospheric temperature increase will probably be accompanied by a reduction in summer precipitation [1]. Climate change will cause potential directional impact on species distribution. Gradual changes that allow ecosystems to slowly adapt. In the IPPC chapter as ecosystems that are adaptive because they are able to change their composition or function in response to changing environmental conditions [2].

Many environmental and biological questions have arisen as a result of this impending transformation. Here, we focus on those related to biodiversity. Losing and moving biological diversity has numerous effects on both natural and social systems, and casts new doubts about conservation planning and policies [3-5] as well as the economic and social impact that the loss of some 
important ecosystem services will have [6,7]. It has been shown in the past that the loss of biodiversity is mainly due to three important factors (and their interaction): (1) changes in land use (fragmentation), (2) the introduction of invasive alien species and (3) global warming [8-11]. The relationships between these three causes cannot be stated with any certainty because they are highly complex and also because of the well-known fact that relationship does not mean causality [12].

Land-use change is a complex process and, once analysed, can be the input to assess interlinked processes such as climatic variability, land degradation, ecosystem stability, and biodiversity [13]. Human population growth and resource use, mediated by changes in climate, land use, and water use, increasingly impact biodiversity $[14,15]$.

Nevertheless, an interesting fact has been observed, one that is closely related to the abovementioned factors and to the definition that the IPPC gives to "ecological adaptation". As was widely reported and reviewed in the last IPCC [2] many plant and animal species have shifted their ranges and altered their abundance and seasonal activities in response to the observed climate change that has taken place over the last decades $[14,16,17]$. When this information is compared to the pale ecological records, the predictions result in large-scale biome shifts and changes in community composition. Although there is strong evidence to believe these changes are occurring, and will keep on doing so, the magnitude of the actual changes is still to be determined and is likely to be very different across geographical areas and ecoregions. However, the differences for every individual species are also considerable, thus leading to the idea that the range shift for each species depends on multiple internal and external traits [18]. Climate change is the main issue on the environmental politics agenda and while it is expected to become a significant driving force behind biodiversity change in the 21st century, it is land use that is projected to remain the foremost impetus of change [19]. Despite climate change and change in land use being key to changes in biodiversity [19-23], the interaction between these two forces is complex and currently not well understood [22-24].

It is assumed that Europe will be highly affected by the range shifts and there is the worrying likelihood of the extinction of species $[9,25,26]$. Some suggest that within Europe, the Mediterranean climate and the grassland ecosystems will experience the greatest proportional change in biodiversity $[15,19,27]$. Mediterranean-type ecosystems are characterized by cold winters and hot dry summers. Predictions for the area say that a large number of mammals will be endangered and, for Spain and North Africa, the changes are expected to be in terms of loss of species, especially in the protected areas [28]. Not only that, but meta-analyses carried out in 2010 by Gonzalez et al. [29] predict that temperate mixed and boreal conifer forests will experience the greatest vulnerability, and vegetation shift projections suggest potential latitudinal biome shifts of up to $400 \mathrm{~km}$. The effect that temperature and changes in land use has on these correlations has been studied on a local scale.

Biodiversity locations can be associated to their spatial coordinates, the temporal instant, and the corresponding covariates. This association facilitates the representation of a biodiversity as a realization of a spatio-temporal stochastic process. Spatio-temporal clustering of biodiversity might indicate the presence of risk factors which are not evenly distributed in space and time. In fact, what is usually of interest is to assess the association of clustering of biodiversity to spatial and seasonal covariates [30].

In this study, we aimed to test whether good predictions about the range shifts can be made on a local scale, and to test whether the results of our predictions follow the trends of the global ones. We identify areas most susceptible to future biodiversity loss. There are many reasons for doing a region-specific study, but the most important would be the fact that, among biomes, there are large differences as to what the causes of the biodiversity changes are [19], and also because many terrestrial species have small geographic ranges and cannot be accounted for in larger scale analyses [9]. Furthermore, while management policies in Spain undoubtedly depend on the European framework [31], region-specific studies can help local policy makers make decisions based on objective facts, and provide them with species-specific information that potentially provides enormous help to better manage protected areas, as well as a useful mechanism to quickly identify areas of biological and conservation interest. This is currently used to select and design protected areas. Changes in 
temperature can carry changes in biodiversity by creating opportunities for previously innocuous alien species by enhancing their reproductive capacity, their survival and their competitive power against the native flora and fauna

In our study, we focused on the region of Catalonia (NE Spain). Catalonia is an area rich in a variety of landscapes and environmental conditions that favour a great diversity in vegetation [32]. Also, the area is suitable for bio-geographical approaches thanks to the large amount of reliable species distribution data that is readily available. The novelty of our study is that we use an original statistical method in which we include both the explanatory variables observed and confounders not observed and in which we perform a spatial adjustment, with the objective to evaluate which factors were associated with the biodiversity changes over time and to evaluate the spatial variation of these changes in Catalonia from 2007 to 2011.

\section{Materials and Methods}

\subsection{Data Setting}

We use a spatio-temporal ecological design. The population studied corresponded to The Natural Heritage and Biodiversity Spanish Inventory (NHBSI) [33], which is the main information knowledge tool for supporting the objectives and targets of Spain's biodiversity policy. It contains biodiversity data with over 30 inventories, catalogues and lists of species for the period of 2007 to 2011. All of this information can be found in the Nature Data Bank [34].

\subsection{Variables and Information Sources}

\subsubsection{Response Variables}

As the response variable, we considered the total number of species (amphibians, reptiles, birds and mammals) in each of the $10 \times 10 \mathrm{~km}$ cells, into which the Spanish Inventory of Natural Heritage and Biodiversity divides all of Catalonia [34].

\subsubsection{Explanatory Variables}

Our explanatory variables of interest were the average of the variations in the maximum and minimum temperatures in each of the cells of one year with respect to the previous year in the period 2007 to 2011. Specifically, the variation on day $k$ was calculated first, such as the difference between the value of the temperature (maximum and minimum) and that occurred on the same day in the previous year. Variations were averaged for the whole period considered and they were stratified by season (spring, summer, autumn and winter).

The maximum and minimum temperature data, recorded daily for the period 1 January 2007 to 31 December 2011, from 190 stations throughout the region of Catalonia, were provided by the Weather Area (Meteorological Service of Catalonia). These data were used to estimate the variations (both annual and by season) of maximum and minimum temperatures in each of the cells (further details can be found in [35]).

Also, for each of the cells we included some spatial variables as control variables: (i) topographic variables-slope, aspect, hill shade and elevation [36,37], (ii) proximity to anthropic areas (these five variables were categorized in quintiles, taking the first as a reference category) and (iii) land use (the variable categorized in eight categories, again the first as the reference) $[19,38]$.

Slope (expressed in degrees) was the steepness or degree of incline of a surface. Here, for a particular location, slope was computed as the maximum rate of change in elevation between the location and its surroundings. Aspect was measured clockwise in degrees from 0 to 360 . Hill shading is a technique used to visualize terrain as shaded relief by illuminating it with a hypothetical light source. Here, the illumination value for each cell was determined by its orientation to the light source which, in turn, was based on slope and aspect and was also measured in degrees, from 0 to 360 . 
Finally, elevation was considered as elevation above sea level and expressed in meters. To obtain topographic variables (DTM) we have used the MET-15 model, which is a regular grid containing orthometric heights distributed according to a $15 \mathrm{~m}$ cell side, and has been created by the Cartographic and Geological Institute of Catalonia [30,39].

The proximity to anthropic areas could be considered as a factor explaining biodiversity loss due to habitat fragmentation. Proximity to anthropic areas was approached through the distances, in metres, from the location of each cell to urban areas, roads and railroads. These distances were constructed by considering a geographical layer in each case. The urban area and road layers were obtained from the Catalan Government's Department of Territory and Sustainability, through the ICGC.

We also used the land use on Catalonia maps $(1: 250,000)$, with classification techniques applied on existing LANDSATMSS images for 1997 and 2002 [40,41]. Additionally, we used orthophoto maps (1:5000) from 2005 to 2007 to create the land use map for 2010 (30 m cell) with an accuracy of over $92 \%$ [42]. Specifically, we assigned the land use map just before the date of each wildfire. We assigned, as the land use for each buffer, only the percentage value corresponding to the principal land use of the buffer within. In this paper, we transformed the twenty-two categories, obtained from the ICGC cover map of Catalonia, into eight categories: coniferous forests, dense forests (tree canopy density of $40 \%$ and more but less than $70 \%$ ), fruit trees and berries, artificial non-agricultural vegetated areas, transitional woodland scrub, natural grassland, mixed forests and other (urban, beaches, sand, bare rocks, burnt areas, and water bodies).

\subsection{Statistical Analysis}

We assumed that in each cell the total number of species (being a discrete variable, i.e., a counting variable) follows a Poisson distribution

$$
O_{i} \sim \operatorname{Poisson}\left(\mu_{i}\right)
$$

where $O_{i}$ denotes the total number of species in the cell $i$.

We are interested in modeling relative risks, which measure the association between the explanatory variables and outcome (the number of species in our case). The relative risk is associated with risk factors by means of spatial ecological regression.

\section{Spatial Adjustment}

In addition to the explanatory variables, there could be other unobserved variables (unobserved confounders) that could be associated with the dependent variable.

When one has a spatial design (as in our case), the most important source of non-observed confounding is "spatial dependence" or clustering. That is to say, cells that are close in space show more similar behavior than cells that are not close. In fact, this dependence could be the consequence of unobserved confounders that were spatially distributed. To capture the spatial dependency, in the regression we included a structured random effect with a Matern structure explicitly constructed through the Stochastic Partial Differential Equation approach [43], indexed by the cell. Further, by introducing an additional unstructured random effect into the model, indexed by the cell, we also controlled for the presence of heterogeneity, that is to say, unobserved variables, invariant over time, that are specific to the unit of analysis.

Given the complexity of our model, we preferred to perform inferences using a Bayesian framework. This approach is considered the most suitable to account for model uncertainty, both in the parameters and in the specification of the models. Moreover, only under the Bayesian approach is it possible to model extra variability with relatively sparse data in some cases. Finally, within the Bayesian approach, specifying a hierarchical structure on the (observable) data and (unobservable) parameters, which are all considered as random quantities, is straightforward. In particular, we followed the Integrated Nested Laplace Approximation (INLA) approach [44], within a (pure) Bayesian framework. As is 
known, in Bayesian analysis the choice of the prior may have a considerable impact on the results. For this reason, we used penalising complexity (PC) priors here [45].

All analyses were performed with the free software R (version 3.4.2) [46] made available through the INLA library [44,47].

\section{Results}

We have estimated a slight increase in daily maximum temperature $(0.773 \%$, annualized on average) and a more significant increase in minimum temperature $(2.960 \%$, annualized on average) (see Figure 1). These values correspond to a 5-year increase of $0.159{ }^{\circ} \mathrm{C}\left(95 \%\right.$ credible interval $0.080{ }^{\circ} \mathrm{C}$, $\left.0.242{ }^{\circ} \mathrm{C}\right)$ in maximum temperature, and an increase of $0.332 \mathrm{C}\left(95 \%\right.$ credible interval $\left.0.008{ }^{\circ} \mathrm{C}, 0.635^{\circ} \mathrm{C}\right)$ in minimum temperature. There was an increase in the spatial variability of daily air temperature (estimated standard deviation equals $7.679{ }^{\circ} \mathrm{C}$, maximum temperature, and $8.742{ }^{\circ} \mathrm{C}$, minimum temperature, in 2008), denoting the existence of space-time interactions. In fact, a geographical pattern could be observed in the variations of daily temperature. It seems that the variation of the temperature depended on the latitude, with a maximum in the latitude corresponding to 4.619 .000 coord Y (ETRS89 31N).

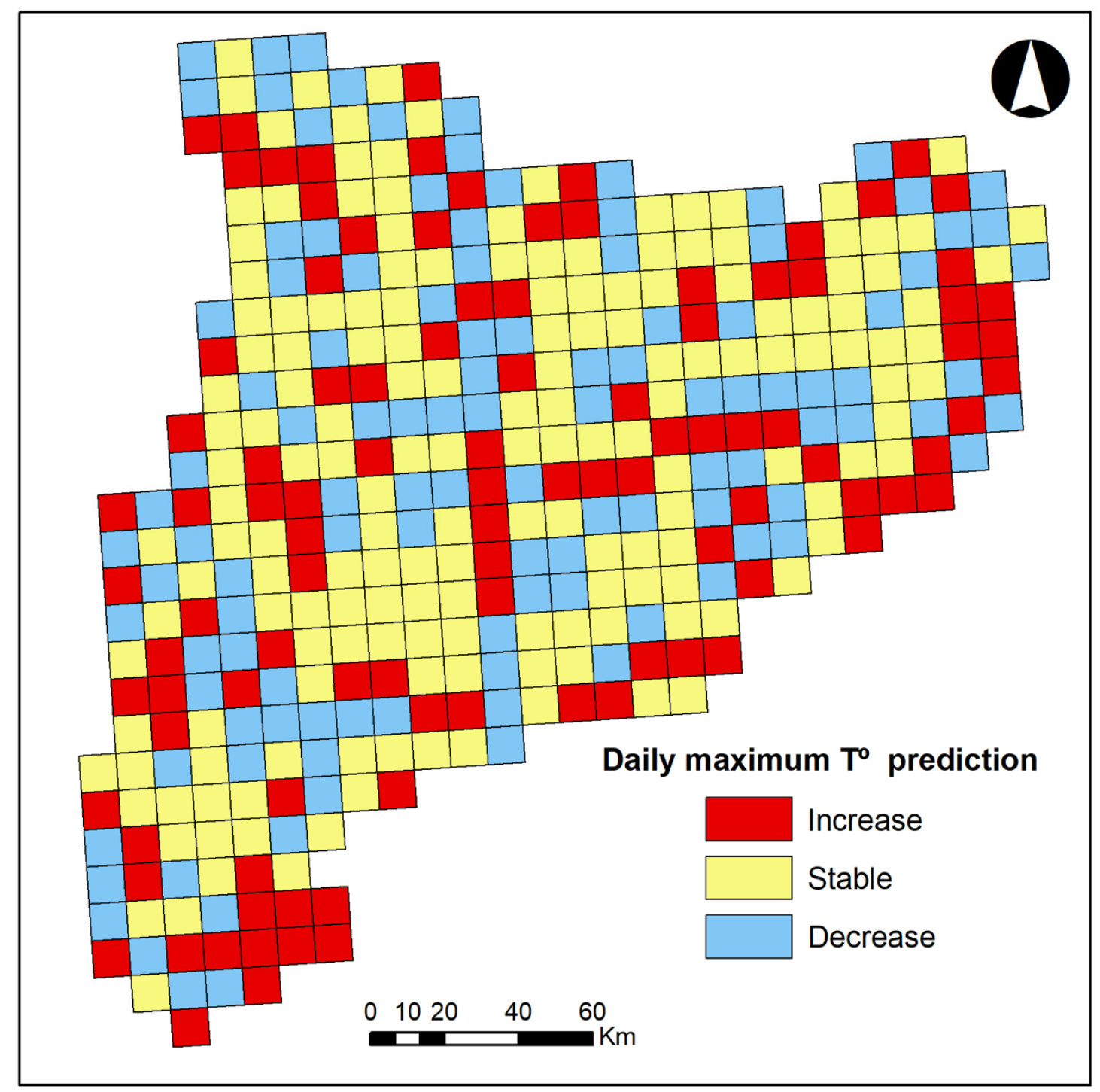

Figure 1. Cont. 


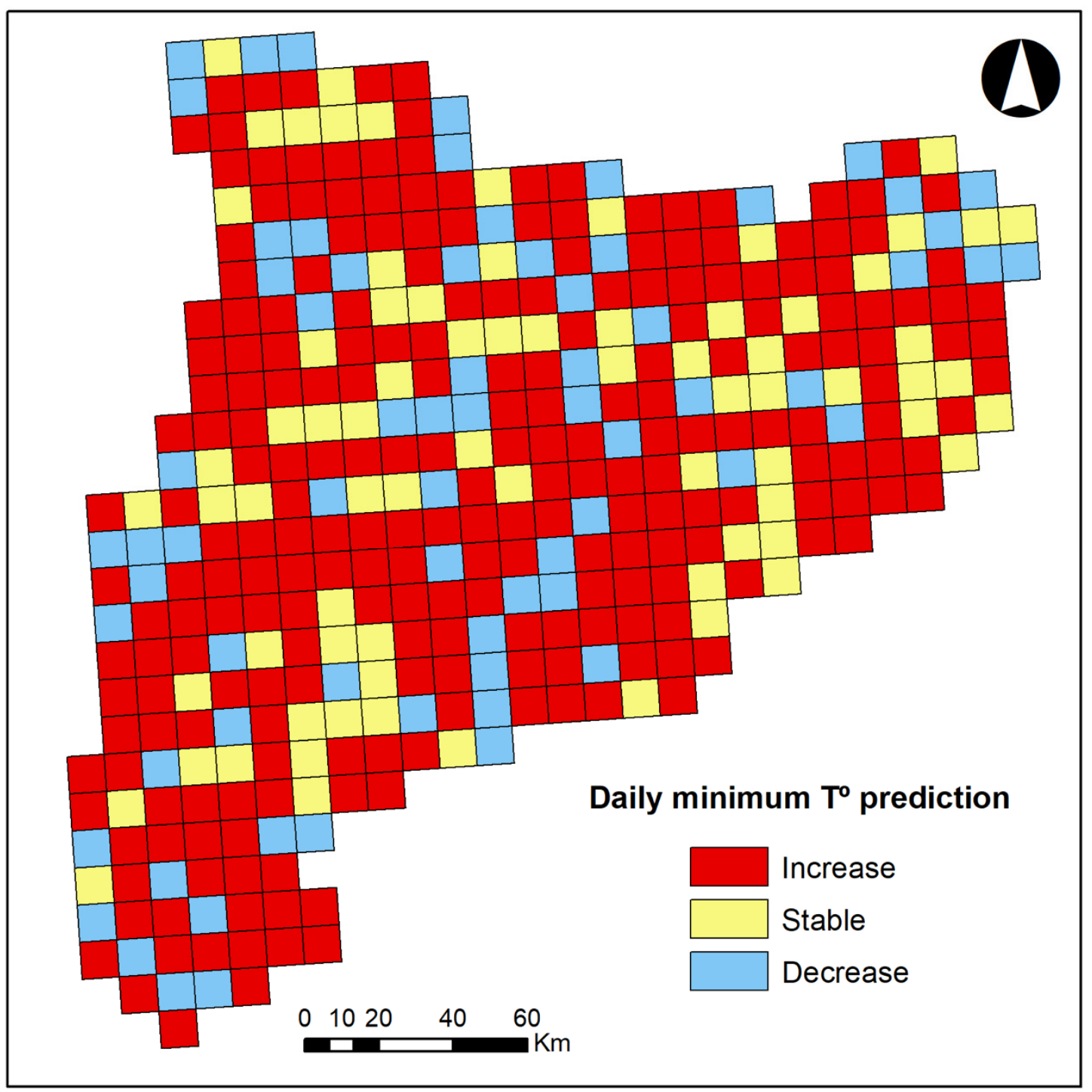

Figure 1. Daily maximum and minimum temperature prediction and latitude variation, with a maximum in 4.619 .000 coord $Y$ (ETRS89 31N).

Furthermore, in our case, the estimated temperature variation was not homogeneous amongst months: This variation has been positive from April to September in maximum temperature and has been positive from May to October in minimum temperature.

The results of the estimation show that the total number of species was greater than expected (relative risk greater than unity) in those cells with some slope (particularly greater than the first quintile, between $0 \%$ and $0.37 \%$ slope) and with land use other than urban (the predominant category in "others", that included urban, beaches, sand, bare rocks, burnt areas, and water bodies) (Table A1 in Appendix A). It should be noted that when the slope of the cell was greater than $7.4 \%$, the total number of species in the cell was estimated between $11.8 \%$ (95\% credibility interval-equivalent to confidence interval-95\% CrI 0.04\%-24.5\%) and 12.9\% (95\% CrI 0.01\%-27.6\%) higher than expected. On the other hand, in the cells whose land use was not urban, the total number of species was between $38.4 \%$, in forests, and $55.2 \%$, in mixed forests, higher than expected. However, in all cases the statistical significance was only marginal (the $90 \%$ credibility intervals did not contain the unity) and the credibility intervals overlap and therefore were not found statistically different (Table A1 in Appendix A). 
In contrast, in those cells closest to inhabited areas and with an orientation of the slope (i.e., aspect) of the fourth quartile, the total number of species was estimated to be lower than expected (i.e., relative risk less than unity; Table A1 in Appendix A). In this sense, when the distance to inhabited areas was less than 180 metres (second quintile) the total number of species was $4.2 \%$ fewer than when the distance was between 180 and $1664 \mathrm{~m}$; and 9.5\% when the distance was greater than $1664 \mathrm{~m}$ (fifth quintile). In addition, when the aspect of the cell was greater than $257.9 \mathrm{~m}$ (fourth quartile), the number of species was $6.4 \%$ less.

We can observe that most invasive species are found in areas where the minimum temperature is expected to increase (Figure 2).

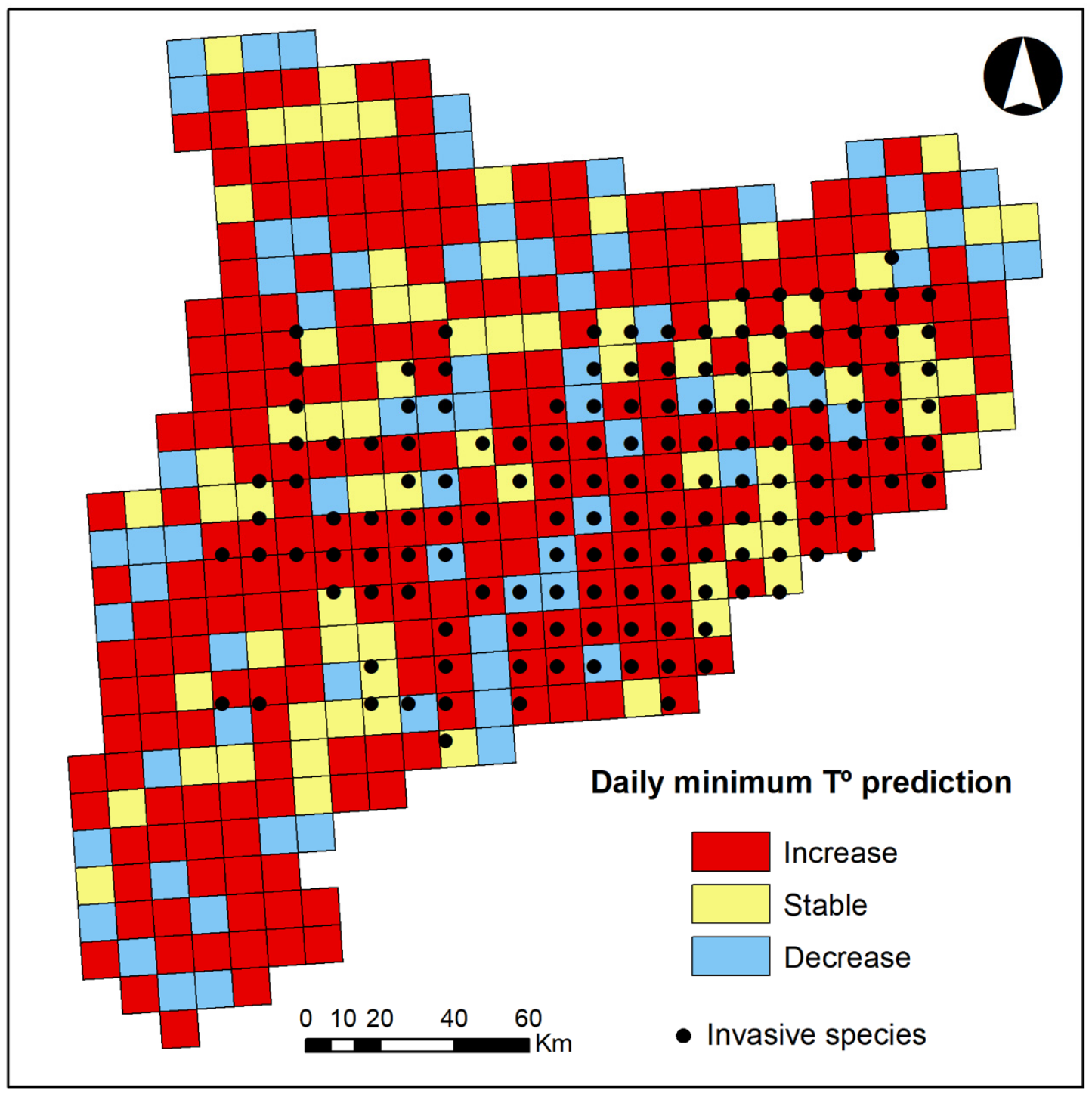

Figure 2. Minimum temperature prediction and invasive species distribution.

Many studies have shown that different species are colonizing new territories due to the increase in temperature. These species look for higher latitudes where they can find their optimal conditions. This study shows that the latitudinal range where the temperature changes are greatest has been calculated locally. On the other hand, we have verified that protected areas where biodiversity accumulates are becoming areas of biodiversity loss at the expense of other areas that are increasing biodiversity because the species seek their optimum at higher latitudes.

Protected areas are crucial for conserving the remaining biodiversity. We estimated the composition of several well-studied taxonomic groups (amphibians, reptiles, birds and mammals), and although it 
is observed that even most protected areas will concentrate the greatest biodiversity, we must consider that new spaces will be colonized by new species and that we will find hotspots outside protected areas (Figure 3).

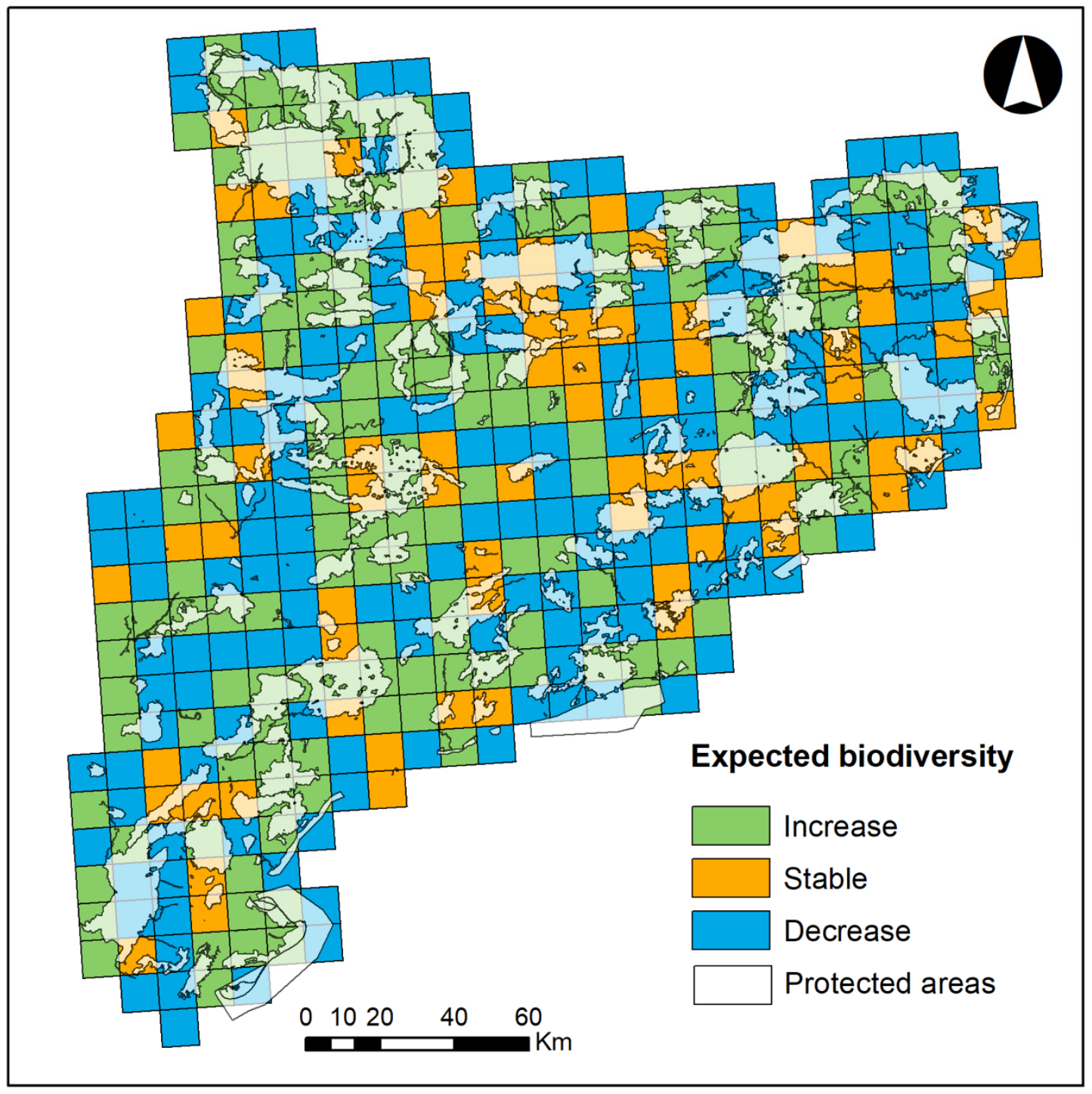

Figure 3. Correspondence between the expected biodiversity and current location of protected areas.

\section{Discussion}

Temperature and land use will lead to broad-scale changes in specie patterns on regional scales. Predictions play an important role in alerting decision-makers to potential future risks and can support the development of management strategies to reduce temperature change impacts on biodiversity.

The establishment of protected areas is traditionally considered indispensable to preserve biodiversity hotspots or areas inhabited by threatened species. The results show that the response of specie richness to the change in temperature could cause a shift between these two areas, i.e., where there is no type of protection measure and invasive species colonize new areas as protected natural areas compete with protected species of great ecological value. Invasive species are defined as a non-native plant, animal or other organism that dominates the new colonized ecosystem. Invasive species can dominate these natural ecosystems by displacing native fauna and flora species. Both situations present a risk for the conservation of biodiversity and hence the study highlights the importance of habitat to 
habitat heterogeneity in Mediterranean landscapes is as a criterion for landscape planning and for defining management directives to preserve this changing biodiversity.

It is important to have a global view of the biodiversity pattern to design and manage protected spaces and biological corridors, hence having a global view of the biodiversity pattern is fundamental. Climate change often is seen as a future problem that is insignificant in comparison to other pressures such as fragmentation $[15,24,38,48]$ but protected areas are geographically fixed and increasingly isolated by habitat destruction, and are therefore poorly suited to accommodating species range shifts due to climate change.

Biodiversity conservation should be planned on large spatial scales, which means increasing the focus on the landscape matrix. Protected areas need to be connected via corridors or "stepping-stone" patches. A lack of these connectivity infrastructures could have a huge effect on overall biodiversity and the efficiency of protected natural areas (protected areas could be islands within fragmented landscapes). The modeling of the expected biodiversity can improve the location of corridors and can help managers to develop conservation strategies and restoration techniques.

\section{Conclusions}

The ranges of plants and animals are moving in response to recent changes in climate. This study shows that the latitudinal range where the temperature changes, calculated locally, are greatest. On the other hand, we have verified that protected areas where biodiversity accumulates are becoming areas of biodiversity loss at the expense of other areas that are increasing in biodiversity because the species seek their optimum at higher latitudes.

A great conservation challenge would be facilitating the movement of species across the landscape matrix so that they can move to sites that, in the future, provide suitable conditions while ensuring the continued viability of individual protected natural areas.

A new policy of design protected areas has been established to contemplate the effects of climate change. Sufficient evidence exists to show that early implementation of new protected areas is important to reduce the threat that climate change poses to biodiversity. Concepts such as connectivity and corridors are much more frequently proposed as responses to climate change.

Author Contributions: D.V. and M.S. had the original idea for the paper. M.S. designed the study. The bibliographic search and the writing of the introduction were carried out by D.V. The methods and statistical analysis were chosen and performed by M.S.; D.V.; M.R. and J.P. created the tables and figures. All authors wrote the results and the discussion. The writing and final editing was done by D.V., M.S., M.R. and J.P. All authors reviewed and approved the manuscript.

Funding: This work was partly funded by the University of Girona (MPCUdG2016, GDRCompetUdG2017 and TRANSFERUdG2016).

Acknowledgments: We appreciate the comments of two anonymous reviewers of a previous version of this work who, without doubt, helped us to improve our work. The usual disclaimer applies.

Conflicts of Interest: The manuscript is an original contribution that has not been published before, whole or in part, in any format, including electronically. All authors will disclose any actual or potential conflict of interest including any financial, personal or other relationships with other people or organizations, that could inappropriately influence or be perceived to influence their work, within three years of beginning the submitted work.

Declaration: We used data from the Nature Data Bank and from the Cartographic and Geological Institute of Catalonia (ICGC). Public and freely accessibles at: http://www.mapama.gob.es/en/biodiversidad/temas/inventariosnacionales/inventario-espanol-patrimonio-natural-biodiv/sistema-indicadores/descarga-datos-abiertos.aspx; http: //www.icgc.cat/en/. 


\section{Appendix A}

Table A1. Results of the estimation of the models explaining the total number of species (amphibians, reptiles, birds and mammals) in each of the $10 \times 10 \mathrm{~km}$ cells in Catalonia, 2007-2011.

\begin{tabular}{|c|c|c|c|}
\hline Variables & Relative Risk & \multicolumn{2}{|c|}{ 95\% Credibility Interval } \\
\hline \multicolumn{4}{|l|}{ Variations in the temperature $\left({ }^{\circ} \mathrm{C}\right)$} \\
\hline Maximum temperature & 1.275 & 0.698 & 2.322 \\
\hline Minimum temperature & 0.933 & 0.493 & 1.767 \\
\hline \multicolumn{4}{|c|}{ Hill shade and elevation [1st Quintile $<161 \mathrm{~m}$ ] } \\
\hline 2nd Quintile 161-334 m & 0.967 & 0.869 & 1.074 \\
\hline 3rd Quintile 335-608 m & 0.945 & 0.826 & 1.079 \\
\hline 4th Quintile $609-1069 \mathrm{~m}$ & 0.968 & 0.825 & 1.132 \\
\hline 5th Quintile 1070-2541 m & 0.968 & 0.801 & 1.166 \\
\hline \multicolumn{4}{|c|}{ Distance to anthropic areas [1st Quintile $<180 \mathrm{~m}$ ] } \\
\hline 2nd Quintile 180-539 m & 0.948 & 0.867 & 1.036 \\
\hline 3rd Quintile 540-905 m & 0.991 & 0.907 & 1.082 \\
\hline 4th Quintile 906-1664 m & 0.976 & 0.891 & 1.068 \\
\hline 5th Quintile 1665-10170 m & 0.905 & 0.822 & 0.997 \\
\hline \multicolumn{4}{|l|}{ Slope [1st Quintile < $0.37 \%$ ] } \\
\hline 2nd Quintile & 1.147 & 1.047 & 1.255 \\
\hline 3rd Quintile & 1.056 & 0.947 & 1.178 \\
\hline 4th Quintile $7.4 \%-11.0 \%$ & 1.118 & 1.004 & 1.245 \\
\hline 5th Quintile $11.0 \%-24.4 \%$ & 1.129 & 1.001 & 1.276 \\
\hline \multicolumn{4}{|l|}{ Aspect [1st Quartile < 93.0] } \\
\hline 2nd Quartile 93.0-174.0 & 1.025 & 0.941 & 1.115 \\
\hline 3rd Quartile 174.1-257.0 & 0.993 & 0.919 & 1.072 \\
\hline 4th Quartile 257.1-357.0 & 0.936 & 0.848 & 1.032 \\
\hline \multicolumn{4}{|l|}{ Land use [Other] } \\
\hline \multicolumn{4}{|l|}{ Coniferous forests } \\
\hline 1997 Cover map & 0.948 & 0.000 & $51,87,048.404$ \\
\hline 2002 Cover map & 1.075 & 0.000 & $5,887,435.884$ \\
\hline 2010 Cover map & 1.486 & 0.881 & 2.512 \\
\hline \multicolumn{4}{|l|}{ Dense forest } \\
\hline 1997 Cover map & 1.077 & 0.000 & $5,897,531.078$ \\
\hline 2002 Cover map & 0.914 & 0.000 & $5,005,564.082$ \\
\hline 2010 Cover map & 1.384 & 0.824 & 2.330 \\
\hline \multicolumn{4}{|l|}{ Fruit trees and berries } \\
\hline 1997 Cover map & 1.032 & 0.000 & $5,647,790.248$ \\
\hline 2002 Cover map & 1.000 & 0.000 & $5,474,699.312$ \\
\hline 2010 Cover map & 1.420 & 0.853 & 2.366 \\
\hline \multicolumn{4}{|c|}{ Artificial, non-agricultural vegetated } \\
\hline 1997 Cover map & 0.911 & 0.000 & $4,993,598.489$ \\
\hline 2002 Cover map & 1.214 & 0.000 & $6,652,178.514$ \\
\hline 2010 Cover map & 1.266 & 0,000 & $6,928,848.938$ \\
\hline \multicolumn{4}{|l|}{ Transitional woodland scrub } \\
\hline 1997 Cover map & 0.988 & 0.000 & $5,404,510.383$ \\
\hline 2002 Cover map & 1.061 & 0.000 & $5,808,358.914$ \\
\hline 2010 Cover map & 1.448 & 0.863 & 2.433 \\
\hline \multicolumn{4}{|l|}{ Natural grassland } \\
\hline 1997 Cover map & 1.256 & 0.000 & $6,905,193.758$ \\
\hline 2002 Cover map & 0.977 & 0.000 & $5,373,630.141$ \\
\hline 2010 Cover map & 1.276 & 0.757 & 2.152 \\
\hline \multicolumn{4}{|l|}{ Mixed forest } \\
\hline 1997 Cover map & 1.418 & 0.000 & $7,762,645.290$ \\
\hline 2002 Cover map & 1.004 & 0.000 & $5,502,696.848$ \\
\hline 2010 Cover map & 1.522 & 0.905 & 2.567 \\
\hline
\end{tabular}

[Reference category between brackets]. Shaded in grey 95\% Credibility interval did not contain 1, shaded in yellow $90 \%$ Credibility interval did not contain 1. 
Relative risk is interpreted as follows $(R R-1) \times 100$. Thus, for example, when the slope of the cell was greater than $7.4 \%$ and less than $18 \%$ (fourth quartile), the total number of species in the cell was estimated at $11.8 \%((1118-1) \times 100)$ higher than expected.

\section{References}

1. Vicente-Serrano, S.M.; López-Moreno, J.I.; Beguería, S.; Lorenzo-Lacruz, J.; Sánchez-Lorenzo, A.; García-Ruíz, J.M.; Azorín-Molina, C.; Morán-Tejeda, E.; Revuelto, J.; Trigo, R.; et al. Evidence of increasing drought severity caused by temperature rise in southern Europe. Environ. Res. Lett. 2014, 9, 044001. [CrossRef]

2. Field, C.B.; Barros, V.R.; Dokken, D.J.; Mach, K.J.; Mastrandrea, M.D.; Bilir, T.E.; Chatterjee, M.; Ebi, K.L.; Estrada, Y.O.; Genova, R.C.; et al. (Eds.) IPCC, 2014: Climate Change 2014: Impacts, Adaptation, and Vulnerability. Part A: Global and Sectoral Aspects. Contribution of Working Group II to the Fifth Assessment Report of the Intergovernmental Panel on Climate Change; Cambridge University Press: Cambridge, UK; New York, NY, USA, 2014.

3. McMahon, S.M.; Harrison, S.P.; Armbruster, W.S.; Bartlein, P.J.; Beale, C.M.; Edwards, M.E.; Kattge, J.; Midgley, G.; Morin, X.; Prentice, I.C. Improving assessment and modelling of climate change impacts on global terrestrial biodiversity. Trends Ecol. Evol. 2011, 26, 249-259. [CrossRef] [PubMed]

4. Iwamura, T.; Guisan, A.; Wilson, K.A.; Possingham, H.P. How robust are global conservation priorities to climate change? Glob. Environ. Chang. 2013, 23, 1277-1284. [CrossRef]

5. Kittel, T.G.F. The Vulnerability of Biodiversity to Rapid Climate Change. In Vulnerability of Ecosystems to Climate; Seastedt, T.R., Suding, K., Eds.; Elsevier Inc.: Oxford, UK; Academic Press: Cambridge, UK, 2013; Volume 4, Chapter 15; pp. 185-201.

6. Perrings, C.; Mäler, K.G.; Folke, C.; Holling, C.; Jansson, B.O. (Eds.) Biodiversity Loss: Economic and Ecological Issues; Cambridge University Press: Cambridge, UK, 1995; p. 332.

7. Díaz, S.; Fargione, J.; Chapin, F.S.; Tilman, D. Biodiversity loss threatens human well-being. PLoS Biol. 2006, 4, e277. [CrossRef]

8. Pimm, S.L.; Raven, P. Biodiversity: Extinction by numbers. Nature 2000, 403, 843-845. [CrossRef]

9. Thomas, C.D.; Cameron, A.; Green, R.E.; Bakkenes, M.; Beaumont, L.J.; Collingham, Y.C.; Erasmus, B.F.; De Siqueira, M.F.; Grainger, A.; Hannah, L. Extinction risk from climate change. Nature 2004, 427, $145-148$. [CrossRef]

10. Walther, G.R.; Roques, A.; Hulme, P.E.; Sykes, M.T.; Pysek, P.; Kühn, I.; Zobel, M.; Bacher, S.; Botta-Dukát, Z.; Bugmann, H. Alien species in a warmer world: Risks and opportunities. Trends Ecol. Evol. 2009, 24, 686-693. [CrossRef]

11. Kovats, S.; Valentini, R.; Bouwer, L.M.; Georgopoulou, E.; Jacob, D.; Martin, E.; Rounsevell, M.; Soussana, J.F. Chapter 23. In IPCC, 2014: Climate Change 2014: Impacts, Adaptation, and Vulnerability. Part A: Global and Sectoral Aspects. Contribution of Working Group II to the Fifth Assessment Report of the Intergovernmental Panel on Climate Change; Cambridge University Press: Cambridge, UK; New York, NY, USA, 2014.

12. Wright, S. Correlation and causation. J. Agric. Res. 1921, 20, 557-585.

13. Veldkamp, A.; Lambin, E.F. Predicting land-use change. Agric. Ecosyst. Environ. 2001, 85, 1-6. [CrossRef]

14. Anderson, J.T.; Panetta, A.M.; Mitchell-Olds, T. Evolutionary and ecological responses to anthropogenic climate change: Update on anthropogenic climate change. Plant Physiol. 2012, 160, 1728-1740. [CrossRef]

15. Klausmeyer, K.R.; Shaw, M.R. Climate change, habitat loss, protected areas and the climate adaptation potential of species in Mediterranean ecosystems worldwide. PLoS ONE 2009, 4, e6392. [CrossRef] [PubMed]

16. Ahola, M.P.; Laaksonen, T.; Eeva, T. Climate change can alter competitive relationships between resident and migratory birds. J. Anim. Ecol. 2007, 76, 1045-1052. [CrossRef] [PubMed]

17. Aitken, S.N.; Yeaman, S.; Holliday, J.A.; Wang, T.; Curtis-Mclane, S. Adaptation, migration or extirpation: Climate change outcomes for tree populations. Evol. Appl. 2008, 1, 95-111. [CrossRef] [PubMed]

18. Chen, I.; Hill, J.K.; Ohlemüller, R.; Roy, D.B.; Thomas, C.D. Rapid range shifts of species of climate warming. Science 2011, 333, 1024-1026. [CrossRef]

19. Sala, O.; Chapin, F.; Armesto, J.; Berlow, E.; Bloomfield, J.; Dirzo, R.; Huber-Sanwald, E.; Huenneke, L.F.; Jackson, R.B.; Kinzig, A.; et al. Global biodiversity scenarios for the year 2100. Science 2000, 287, 1770-1774. [CrossRef] 
20. Hansen, A.J.; Neilson, R.P.; Dale, V.H.; Flather, C.H.; Iverson, L.R.; Currie, D.J.; Shafer, S.; Cook, R.; Bartlein, P.J. Global change in forests: Responses of species, communities, and biomes interactions between climate change and land use are projected to cause large shifts in biodiversity. Bioscience 2001, 51, 765-779. [CrossRef]

21. Brooker, R.W.; Travis, J.M.; Clark, E.J.; Dytham, C. Modelling species' range shifts in a changing climate: The impacts of biotic interactions, dispersal distance and the rate of climate change. J. Theor. Biol. 2007, 245, 59-65. [CrossRef]

22. Mawdsley, J.R.; O'Malley, R.; Ojima, D.S. A Review of Climate-Change Adaptation Strategies for Wildlife Management and Biodiversity Conservation. Conserv. Biol. 2009, 23, 1080-1089. [CrossRef]

23. Perrings, C.; Duraiappah, A.; Larigauderie, A.; Mooney, H. The biodiversity and ecosystem services science-policy interface. Science 2011, 331, 1139-1140. [CrossRef]

24. Lepers, E.; Lambin, E.F.; Janetos, A.C.; Defries, R.; Achard, F.; Ramankutty, N.; Scholes, R.J. A synthesis of information on rapid land-cover change for the period 1081-2000. Bioscience 2005, 55, 115-124. [CrossRef]

25. Thuiller, W.; Lavorel, S.; Araújo, M.B.; Sykes, M.T.; Prentice, I.C. Climate change threats to plant diversity in Europe. Proc. Natl. Acad. Sci. USA 2005, 102, 8245-8250. [CrossRef] [PubMed]

26. Araújo, M.B.; Alagador, D.; Cabeza, M.; Nogués-Bravo, D.; Thuiller, W. Climate change threatens European conservation areas. Ecol. Lett. 2011, 14, 484-492. [CrossRef]

27. Giorgi, F. Climate change hot-spots. Geophys. Res. Lett. 2006, 33, L08707. [CrossRef]

28. Maiorano, L.; Falcucci, A.; Zimmermann, N.E.; Psomas, A.; Pottier, J.; Baisero, D.; Rondinini, C.; Guisan, A.; Boitani, L. The future of terrestrial mammals in the Mediterranean basin under climate change. Philos. Trans. R. Soc. Lond. Ser. B Biol. Sci. 2011, 366, 2681-2692. [CrossRef] [PubMed]

29. Gonzalez, P.; Neilson, R.P.; Lenihan, J.M.; Drapek, R.J. Global patterns in the vulnerability of ecosystems to vegetation shifts due to climate change. Glob. Ecol. Biogeogr. 2010, 19, 755-768. [CrossRef]

30. Serra, L.; Juan, P.; Varga, D.; Mateu, J.; Saez, M. Spatial pattern modelling of wildfires in Catalonia, Spain 2004-2008. Environ. Model. Softw. 2012, 40, 235-244. [CrossRef]

31. European Parliament Resolution of 20 April 2012. Our Life Insurance, Our Natural Capital: An EU Biodiversity Strategy to 2020. Available online: http://ec.europa.eu/environment/nature/biodiversity/ comm2006/pdf/EP_resolution_april2012.pdf (accessed on 3 February 2018).

32. Torras, O.; Martín-Queller, E.; Saura, S. Relating landscape structure, environment and management to biodiversity indicators estimated from forest inventory data in Catalonia (NE Spain). For. Syst. 2009, 18, 322-337. [CrossRef]

33. Ministry of Agriculture and Fisheries, Food and Environment. Spanish Inventory of Natural Heritage and Biodiversity [in Spanish]. Ministry of Agriculture and Fisheries, Food and Environment, Government of Spain: Madrid, Spain, 2015. Available online: http://www.mapama.gob.es/es/biodiversidad/temas/ inventarios-nacionales/inventario-espanol-patrimonio-natural-biodiv (accessed on 3 February 2018).

34. Ministry of Agriculture and Fisheries, Food and Environment. Open Data. Spanish Inventory of Natural Heritage and Biodiversity [in Spanish]. Ministry of Agriculture and Fisheries, Food and Environment, Government of Spain: Madrid, Spain, 2015. Available online: http://www.mapama.gob.es/en/biodiversidad/temas/inventarios-nacionales/inventario-espanolpatrimonio-natural-biodiv/sistema-indicadores/descarga-datos-abiertos.aspx (accessed on 3 February 2018).

35. Saez, M.; Barceló, M.A.; Tobías, A.; Varga, D.; Ocaña-Riola, R.; Juan, P.; Mateu, J. Space-time interpolation of daily air temperatures. J. Environ. Stat. 2012, 3. Available online: http://www.jenvstat.org/v03/i05/paper (accessed on 3 February 2018).

36. Coblentz David, D.; Riitters Kurt, H. Topographic controls on the regional-scale biodiversity of the south-western USA. J. Biogeogr. 2004, 31, 1125-1138. [CrossRef]

37. Badgley, C.; Smiley, T.M.; Terry, R.; Davis, E.B.; DeSantis, L.R.; Fox, D.L.; Hopkins, S.S.; Jezkova, T.; Matocq, M.D.; Matzke, N.; et al. Biodiversity and topographic complexity: Modern and geohistorical perspectives. Trends Ecol. Evol. 2017, 32, 211-226. [CrossRef]

38. Newbold, T.; Hudson, L.N.; Hill, S.L.; Contu, S.; Lysenko, I.; Senior, R.A.; Börger, L.; Bennett, D.J.; Choimes, A.; Collen, B.; et al. Global effects of land use on local terrestrial biodiversity. Nature 2015, 520, 45. [CrossRef] [PubMed]

39. Cartographic and Geological Institute of Catalonia. Available online: http://www.icgc.cat/en/ (accessed on 3 February 2018). 
40. Röder, A.; Udelhoven, T.; Hill, J.; del Barrio, G.; Tsiourlis, G. Trend analysis of Landsat-TM and -ETM+ imagery to monitor grazing impact in a rangeland ecosystem in Northern Greece. Remote Sens. Environ. 2008, 112, 2863-2875. [CrossRef]

41. Chuvieco, E.; Aguado, I.; Yebra, Y.; Nieto, H.; Salas, J.; Martín, M.P.; Vilar, L.; Martínez, J.; Martín, S.; Ibarra, P.; et al. Development of a framework for fire risk assessment using remote sensing and geographic information system technologies. Ecol. Model. 2010, 221, 46-58. [CrossRef]

42. Vidal-Macua, J.J.; Zabala, A.; Ninyerol, M.; Pons, X. Developing spatially and thematically detailed back dated maps for land cover studies. Int. J. Digit. Earth 2017, 10, 175-206. [CrossRef]

43. Lindgren, F.; Rue, H.; Lindström, J. An explicit link between Gaussian fields and Gaussian Markov random fields: The stochastic partial differential equation approach (with discussion). J. R. Stat. Soc. Ser. B 2011, 73, 423-498.

44. Rue, H.; Martino, S.; Chopin, N. Approximate Bayesian inference for latent Gaussian models by using integrated nested Laplace approximations (with discussion). J. R. Stat. Soc. Ser. B 2009, 71, 319-392. [CrossRef]

45. Simpson, D.P.; Rue, H.; Martins, T.G.; Riebler, A.; Sørbye, S.H. Penalising model component complexity: A principled, practical approach to constructing priors (with discussion). Stat. Sci. 2017, 32, 1-46. [CrossRef]

46. R Core Team. R: A Language and Environment for Statistical Computing; R Foundation for Statistical Computing: Vienna, Austria, 2017. Available online: https://www.R-project.org/ (accessed on 25 November 2017).

47. R INLA Project 2018. Available online: http://www.r-inla.org/home (accessed on 3 February 2018).

48. Williams, A.P.; Allen, C.D.; Macalady, A.K.; Griffin, D.; Woodhouse, C.A.; Meko, D.M.; Swetnam, T.W.; Rauscher, S.A.; Seager, R.; Grissino-Mayer, H.D.; et al. Temperature as a potent driver of regional forest drought stress and tree mortality. Nat. Clim. Chang. 2013, 3, 292-297. [CrossRef]

(C) 2019 by the authors. Licensee MDPI, Basel, Switzerland. This article is an open access article distributed under the terms and conditions of the Creative Commons Attribution (CC BY) license (http://creativecommons.org/licenses/by/4.0/). 